\title{
The Effect of Soil Physico-chemical Properties on Rhizome Rot and Wilt Disease Complex Incidence of Ginger Under Hill Agro-climatic Region of West Bengal
}

\author{
B. R. Sharma ${ }^{1}$, S. Dutta ${ }^{2 *}$, S. Roy ${ }^{3}$, A. Debnath ${ }^{3}$ and M. De Roy ${ }^{4}$ \\ ${ }^{1}$ CoochBehar, RRS, UBKV Kalimpong, India; ${ }^{2}$ Department of Plant Pathology, BCKV, Mohanpur, Nadia, West Bengal, India \\ ${ }^{3}$ Department of Plant Pathology, UBKV, Pundibari \\ ${ }^{4} A D O$ (Farm), DSF, CoochBehar, W. Bengal, India, Presently Asst. Ananlytical Chemist, Soil Testing Laboratory, Berhampore
}

(Received on July 16, 2009; Accepted on March 3, 2010)

\begin{abstract}
A study was conducted to find out the relationship of physico-chemical properties (viz. organic carbon(OC), $\mathrm{pH}$, electrical conductivity, nitrogen, phosphorus and potassium content) of ginger growing soil with incidence percentage of rhizome rot and wilt disease complex of ginger. Organic carbon content and $\mathrm{pH}$ of the ginger soil contributed significantly $(93 \%)$ in the prediction of ginger rhizome rot and wilt disease complex incidence with negative correlation. Soil having weak acidic reaction with $\mathrm{OC}$ percent greater than $\mathbf{2 . 2 5}$ was observed to have the lower average incidence of the disease.
\end{abstract}

Keywords : ginger, rhizome rot and wilt disease, soil physico-chemical properties

Ginger (Zingiber officinale Rose.) is an important commercial spice crop grown for its aromatic rhizomes, which are used both as a spice and a medicine. At present, India is the largest producer of ginger in the world accounting for about one-third of the total world output followed by Thailand and Japan. The leading Ginger growing Indian states are Kerala, Karnataka, West Bengal, Andhra Pradesh, Orissa, Meghalaya, Mizoram, Arunachal Pradesh, Sikkim and Himachal Pradesh. Diseases are important production constraints of ginger and often associated with Ralstonia solanacearum, Pythium spp., Fusarium oxysporum and Pratylenchus coffeae (Rajan et al., 2002). The crop suffers from several diseases among which bacterial wilt (Ralstonia solanacearum) is a serious problem in Kerala and North-Eastern region of the country especially in Sikkim and West Bengal (Sarma and Anandaraj, 2000). Kim et al. (1997) reported that $\mathrm{pH}$ range of 6.0-7.0 was found to be optimum for the growth of the Pythium myriotylum, the causal agent of rhizome rot of ginger. The lower rhizome rot incidence found in Wanjoo area of Korea Republic where soil were more sandy, lower in $\mathrm{pH}$ and has less

\footnotetext{
*Corresponding author.

Phone)+91-3325828407 FAX) +91-3325828407

E-mail) subrata_mithu@yahoo.co.in
}

organic matter, $\mathrm{P}_{2} \mathrm{O}_{5}$ and exchangeable cation. Consistent relationships between disease severity and soil physiochemical properties were not found (Kim et al., 1996). Soil from Eunhari in Korea suppressive to rhizome rot caused by Pythium zingiberum and Fusarium oxysporum f. sp. zingiberi had a higher clay content and lower $\mathrm{pH}$ than the conducive Eouri and Eunhari soil. The percentage of germination of Fusarium oxysporum f. sp. zingiberi conidia was lowest on Eunhari soil and germ tube growth was inhibited to a greater extent than on the other two soils (Lee et al., 1990). Hence, the present investigation was carried out to study the relationship between disease severity and soil physico-chemical properties.

A study was conducted at Regional Research Station (Hill zone), Uttar Banga Krishi Viswavidyalaya, Kalimpong, during the year 2005 to find out the relationship of physicochemical properties of ginger growing soil with disease incidence percentage of rhizome rot and wilt disease complex of ginger. The Kalimpong sub-division under Darjeeling district is a part of northern hill region of West Bengal situated between $26^{\circ} 51^{\prime} \mathrm{N}$ and $27^{\circ} 12^{\prime} \mathrm{N}$ latitude and $88^{\circ} 28^{\prime} \mathrm{E}$ and $88^{\circ} 53^{\prime} \mathrm{E}$ longitude. The topography is mainly hilly terrain and is characterized by anticline and syncline with undeveloped horizon of brown forest soil. The annual rainfall varies from 2100 to $3000 \mathrm{~mm}$, of which $80 \%$ is received during June to October. Minimum and maximum temperature of the area varies from $2-4^{\circ} \mathrm{C}$ and $26-30^{\circ} \mathrm{C}$ respectively. The variation in humidity is also an important characteristic feature of the region. The relative humidity of the area varies from $65 \%$ to $98 \%$. This complex agroecological condition is conducive for disease and insect pest attack. A survey was undertaken in twenty different locations of hill region (Kalimpong Block I, II and III) of West Bengal. In all the twenty locations data related to relative disease incidence of rhizome rot and wilt disease complex of ginger in $2 \mathrm{~m}^{2}$ marked area of five different spots by random sampling in farmers field were recorded. The disease incidence percent (DI \%) of the specific location was calculated by following procedure. 
DI $\%=\frac{\text { Number of clumps wilted }}{\text { Total number of clumps present in the marked area }} \times 100$

Soil samples collected from twenty different locations were analyzed for their physico-chemical properties (viz. organic carbon, $\mathrm{pH}$, electrical conductivity, nitrogen, phosphorus and potassium content) for correlation study. Electrical Conductivity (EC) and $\mathrm{pH}$ was estimated through Systronics electrical conductivity meter and $\mathrm{pH}$ meter (model number 303 and 335 respectively). Organic carbon (Walkley and Black, 1934), Nitrogen (Jackson, 1967), Phosphorous (Bray and Kurtz, 1945) and Potassium (Baruah and Bathakur, 1997) were estimated by standard procedure. Isolation of pathogenic bacteria was done from ginger growing soil of Kalimpong subdivision by dilution plating method on TZC (Tetrazolium chloride) medium. The soil suspension thus obtained was used for isolation of pathogenic fungi by dilution plating method on Potato Dextrose Agar (PDA) with carbendazim (50 ppm) and Pythium specific medium.

The physico-chemical parameters of soil of ginger growing plots (organic carbon, $\mathrm{pH}$, electrical conductivity, nitrogen, phosphorus and potassium) having different degree of rhizome rot and wilt disease complex incidence were estimated and put to regression as independent vari- ables and disease incidence (DI) percent as dependent variables (Tables 1 and 2). The result of the step-wise regression is presented in the Tables 3 and 4. Correlation coefficient between all the physico-chemical parameters of ginger growing soils of Kalimpong sub-division with DI and within themselves has been presented in Table 2a. Data indicated that $\mathrm{pH}$ and organic carbon (OC) content of ginger growing soil from different locations of Kalimpong sub-division showed negative correlation with DI percent. Further, the value of coefficient of multiple determination $\left(\mathrm{R}^{2}\right)$ was 0.9542 which implies that 95.42 percent of variation in the development of rhizome rot and wilt disease complex of ginger is explained by the six independent variables viz., organic carbon, $\mathrm{pH}$, electrical conductivity, nitrogen, phosphorus and potassium. Even some of the parameters showed high correlation within themselves i.e., the independent variables considered here do have certain amount of interdependence. So, step-wise regression was performed to eliminate the parameters having interdependence to find the most important determinants contributing to the disease incidence. Regression model with soil physico-chemical parameters, which contribute to disease incidence, were presented in Table $2 b$. Initially three parameters were dropped and then step-wise regression was performed. After removal of $\mathrm{X}_{3}$ parameter from the equa-

Table 1. Relationship of disease incidence percent with $\mathrm{pH}$, EC, Organic carbon, N, P, K in different location of Hill region of Kalimpong sub-division of West Bengal

\begin{tabular}{llccccccc}
\hline \hline Sl. No. & Location of plots & $\mathrm{OC} \%$ & $\mathrm{pH}$ & $\begin{array}{c}\mathrm{EC} \\
\mathrm{mmhos} / \mathrm{cm}\end{array}$ & $\begin{array}{c}\mathrm{N} \text { content } \\
\mathrm{Kg} / \mathrm{ha}\end{array}$ & $\begin{array}{c}\mathrm{P}_{2} \mathrm{O}_{5} \text { content } \\
(\mathrm{ppm})\end{array}$ & $\begin{array}{c}\mathrm{K}_{2} \mathrm{O} \text { content } \\
(\mathrm{g} / \mathrm{kg} \text { soil })\end{array}$ & $\begin{array}{c}\text { Disease } \\
\text { incidence } \%\end{array}$ \\
\hline 1 & Bhalukhop-I & 1.78 & 5.78 & 0.19 & 118.3 & 16.65 & 0.79 & 40 \\
2 & Bhalukhop-II & 2.25 & 5.89 & 0.26 & 120.3 & 20.60 & 1.02 & 30 \\
3 & Bhagey I & 1.39 & 5.27 & 0.17 & 115.6 & 21.21 & 1.53 & 70 \\
4 & Sangsay I & 1.78 & 5.37 & 0.10 & 122.6 & 21.16 & 1.13 & 30 \\
5 & Takling I & 2.92 & 6.17 & 0.25 & 125.6 & 21.70 & 0.60 & 10 \\
6 & Takling II & 1.94 & 5.68 & 0.17 & 116.2 & 17.23 & 0.68 & 55 \\
7 & Soreng I & 2.79 & 6.12 & 0.18 & 120.2 & 15.49 & 0.54 & 12 \\
8 & Upper Menchu I & 2.12 & 5.19 & 0.23 & 108.9 & 21.32 & 1.28 & 51 \\
9 & Sakyong I & 1.80 & 5.47 & 0.32 & 122.8 & 21.72 & 0.39 & 62 \\
10 & Kagey I & 1.52 & 5.52 & 0.19 & 106.3 & 15.45 & 0.40 & 58 \\
11 & Kagey II & 3.19 & 5.76 & 0.12 & 96.4 & 17.05 & 0.72 & 11 \\
12 & Dara Gaon I & 1.67 & 5.04 & 0.10 & 118.3 & 17.73 & 0.65 & 66 \\
13 & Faper Khati I & 2.47 & 5.14 & 0.09 & 62.4 & 18.87 & 0.49 & 41 \\
14 & Gorubathan Tar I & 1.02 & 4.82 & 0.12 & 113.8 & 20.70 & 0.41 & 90 \\
15 & Chisopani I & 1.97 & 5.11 & 0.17 & 108.3 & 16.18 & 0.42 & 58 \\
16 & Munsoong I & 1.49 & 4.80 & 0.18 & 117.4 & 20.19 & 1.33 & 71 \\
17 & Pabak I & 2.95 & 6.00 & 0.23 & 124.9 & 19.80 & 0.60 & 09 \\
18 & Nim Busty I & 1.33 & 5.12 & 0.19 & 119.1 & 21.20 & 1.61 & 76 \\
19 & Posyore I & 3.14 & 6.06 & 0.21 & 123.6 & 12.40 & 0.91 & 0.56 \\
20 & Lingsey I & 1.27 & 6.33 & 0.23 & 12.0 & 20.90 & 0.56 & 21 \\
\hline
\end{tabular}

OC, Organic carbon; EC, Electrical Conductivity 
Table 2. Correlation matrix of the multiple regression model including all the six independent variables (soil physico-chemical parameters) with the dependent variable (DI \%)

\begin{tabular}{|c|c|c|c|c|c|c|c|}
\hline & $\begin{array}{l}\mathrm{OC} \\
\mathrm{X}_{1}\end{array}$ & $\begin{array}{l}\mathrm{pH} \\
\mathrm{X}_{2}\end{array}$ & $\begin{array}{l}\text { EC } \\
X_{3}\end{array}$ & $\begin{array}{c}\text { N-content } \\
\mathrm{X}_{4}\end{array}$ & $\begin{array}{c}\text { P-content } \\
\mathrm{X}_{5}\end{array}$ & $\begin{array}{c}\text { K-content } \\
\mathrm{X}_{6}\end{array}$ & $\begin{array}{l}\text { DI } \\
\text { Y }\end{array}$ \\
\hline $\mathrm{X} 1$ & 1.000 & 0.546 & 0.114 & -0.1203 & -0.2415 & -0.2075 & $-0.8212 * *$ \\
\hline $\mathrm{X} 2$ & & 1.000 & 0.408 & 0.364 & -0.089 & -0.238 & $-0.874 * *$ \\
\hline $\mathrm{X} 3$ & & & 1.000 & 0.513 & 0.343 & -0.012 & -0.198 \\
\hline $\mathrm{X} 4$ & & & & 1.000 & 0.255 & 0.193 & -0.094 \\
\hline X5 & & & & & 1.000 & 0.446 & 0.149 \\
\hline X6 & & & & & & 1.000 & 0.218 \\
\hline $\mathrm{Y}$ & & & & & & & 1.000 \\
\hline
\end{tabular}

At $5 \%$ level of significance $r=0.602$ and at $1 \%$ level of significance $r=0.679$

Table 3. Coefficient of regression models to estimate the DI (\%) based on different ginger growing soils' physico-chemical properties as independent variable at different steps

\begin{tabular}{ccccccccc}
\hline \hline \multirow{2}{*}{ Steps } & $\mathrm{OC} \%$ & $\mathrm{pH}$ & $\mathrm{EC}$ & $\mathrm{N}$ & $\mathrm{P}_{2} \mathrm{O}_{5}$ & $\mathrm{~K}_{2} \mathrm{O}$ & Interception & DI \% \\
& $\mathrm{X}_{1}$ & $\mathrm{X}_{2}$ & $\mathrm{X}_{3}$ & $\mathrm{X}_{4}$ & $\mathrm{X}_{5}$ & $\mathrm{X}_{6}$ & & $\mathrm{Y}$ \\
\hline $\mathrm{I}$ & -18.23 & -36.94 & 55.75 & - & - & - & 275.33 & 0.9461 \\
$\mathrm{II}$ & -19.00 & -33.44 & - & - & - & - & 267.79 & 0.9326 \\
\hline
\end{tabular}

Table 4. Multiple regression analysis for prediction of ginger rhizome rot and wilt disease complex

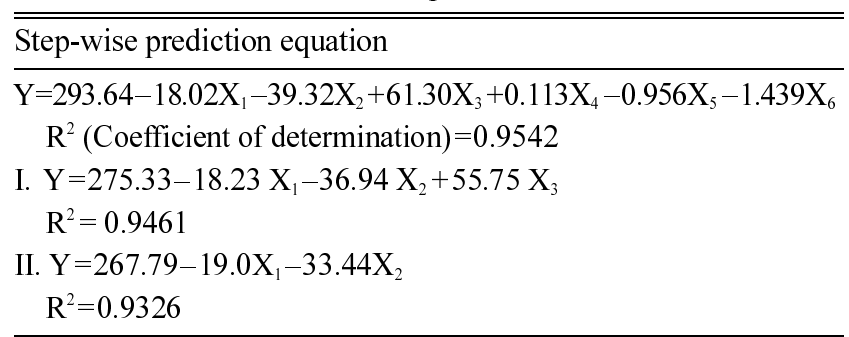

tion, it still shows very high correlation coefficient $\left(\mathrm{R}^{2}=\right.$ 0.9326). Therefore, $\mathrm{pH}$ and organic carbon content of the ginger growing soil contributed significantly (93\%) in the prediction of ginger rhizome rot and wilt disease complex incidence.

The results of the present investigation brought out the relationship between $\mathrm{pH}$ and organic matter content of the soil and with incidence of rhizome rot and wilt disease complex of ginger. From the Table 5 it is indicated that in weakly acidic soil with OC percent $>2.25$ had lower average incidence of the disease whereas in soils with $\mathrm{pH}$ 5.0 to 5.5 and OC content $>2.25$ percent, the average disease incidence was 41.0 percent. But in the plots with $\mathrm{pH}$ 5.0 to 5.5 and $\mathrm{OC}$ percent $<2.25$, the disease incidence was nearly 64 percent. Perusal of the data presented in Table 1 indicated that the incidence of rhizome rot and wilt disease complex of ginger in the area might have negative correlation with $\mathrm{pH}$ and organic matter content of the soil would appear to be the most effective associative factor influencing the disease incidence.
Table 5. Effect of different levels of OC content at varied level of soil $\mathrm{pH}$ on rhizome rot and wilt disease severity

\begin{tabular}{|c|c|c|c|c|}
\hline $\mathrm{pH}$ & $\mathrm{OC}$ & $\begin{array}{l}\text { Location of the } \\
\text { plots }\end{array}$ & DI \% & $\underset{\%}{\text { Average DI }}$ \\
\hline $\begin{array}{l}5.5 \text { and } \\
\text { above }\end{array}$ & $>2.25 \%$ & $\begin{array}{l}\text { Bhalukhop II } \\
\text { Takling I } \\
\text { Soreng I } \\
\text { Kagey II } \\
\text { Pabak I } \\
\text { Posyare I }\end{array}$ & $\begin{array}{r}30 \\
10 \\
12 \\
11 \\
9 \\
8\end{array}$ & 13.33 \\
\hline $\begin{array}{l}5.5 \text { and } \\
\text { above }\end{array}$ & $<2.25 \%$ & $\begin{array}{l}\text { Bhalukhop I } \\
\text { Sansey I } \\
\text { Takling II } \\
\text { Kagey I } \\
\text { Lingsey I }\end{array}$ & $\begin{array}{l}40 \\
30 \\
55 \\
58 \\
21\end{array}$ & 40.80 \\
\hline 5.0 to 5.5 & $>2.25 \%$ & Faper Kheti I & 41 & 41.00 \\
\hline 5.0 to 5.5 & $<2.25 \%$ & $\begin{array}{l}\text { Bhagey I } \\
\text { Upper Menchu I } \\
\text { Sakyong I } \\
\text { Dara Gaon I } \\
\text { Chisopani I } \\
\text { Nim Busty I }\end{array}$ & $\begin{array}{l}70 \\
51 \\
62 \\
66 \\
58 \\
76\end{array}$ & 63.83 \\
\hline$<5.0$ & $<2.25 \%$ & $\begin{array}{l}\text { Gorubathan Tar I } \\
\text { Munsoong I }\end{array}$ & $\begin{array}{l}90 \\
71\end{array}$ & 80.50 \\
\hline
\end{tabular}

OC, Organic carbon

The enumerations of pathogen population present in the rhizome rot and wilt complex infested soil was presented in Table 6. The perusal of the data presented indicated that Fusarium sp., Pythium sp. and Ralstonia solanacearum were present in all the soil samples collected from twenty villages under Kalimpong sub-division. However, highest 
Table 6. Studies on enumeration of associated pathogen population in rhizome rot and wilt complex disease affected soil of Kalimpong sub-division

\begin{tabular}{clcccc}
\hline \hline \multirow{2}{*}{ Sl. No. } & Location of plots & \multirow{2}{*}{$\begin{array}{c}\text { Disease } \\
\text { incidence } \%\end{array}$} & \multicolumn{2}{c}{ Population of associated pathogen/gm of soil } \\
\cline { 4 - 5 } & & & Fusarium spp. & Pythium spp. & Ralstonia solanacearum \\
\hline 1 & Bhalukhop-I & 40 & $4.5 \times 10^{3}$ & $2.9 \times 10^{3}$ & $1.2 \times 10^{6}$ \\
2 & Bhalukhop-II & 30 & $4.1 \times 10^{3}$ & $3.0 \times 10^{3}$ & $5.7 \times 10^{5}$ \\
3 & Bhagey I & 70 & $4.3 \times 10^{3}$ & $3.7 \times 10^{3}$ & $5.1 \times 10^{6}$ \\
4 & Sangsay I & 30 & $4.1 \times 10^{3}$ & $3.3 \times 10^{3}$ & $6.1 \times 10^{5}$ \\
5 & Takling I & 10 & $2.7 \times 10^{3}$ & $2.6 \times 10^{3}$ & $3.4 \times 10^{5}$ \\
6 & Takling II & 55 & $4.8 \times 10^{3}$ & $3.2 \times 10^{3}$ & $2.1 \times 10^{6}$ \\
7 & Soreng I & 12 & $3.8 \times 10^{3}$ & $2.2 \times 10^{3}$ & $3.2 \times 10^{5}$ \\
8 & Upper Menchu I & 51 & $3.7 \times 10^{3}$ & $3.4 \times 10^{3}$ & $4.2 \times 10^{6}$ \\
9 & Sakyong I & 62 & $4.1 \times 10^{3}$ & $3.6 \times 10^{3}$ & $4.9 \times 10^{6}$ \\
10 & Kagey I & 58 & $4.6 \times 10^{3}$ & $3.4 \times 10^{3}$ & $5.5 \times 10^{6}$ \\
11 & Kagey II & 11 & $3.2 \times 10^{3}$ & $2.7 \times 10^{3}$ & $3.0 \times 10^{5}$ \\
12 & Dara Gaon I & 66 & $4.7 \times 10^{3}$ & $3.8 \times 10^{3}$ & $4.9 \times 10^{6}$ \\
13 & Faper Khati I & 41 & $4.4 \times 10^{3}$ & $4.2 \times 10^{3}$ & $9.2 \times 10^{5}$ \\
14 & Gorubathan Tar I & 90 & $5.8 \times 10^{3}$ & $4.2 \times 10^{3}$ & $9.8 \times 10^{6}$ \\
15 & Chisopani I & 58 & $4.1 \times 10^{3}$ & $3.7 \times 10^{3}$ & $5.7 \times 10^{6}$ \\
16 & Munsoong I & 71 & $4.2 \times 10^{3}$ & $3.1 \times 10^{3}$ & $6.9 \times 10^{6}$ \\
17 & Pabak I & $3.5 \times 10^{3}$ & $3.1 \times 10^{3}$ & $2.7 \times 10^{5}$ \\
18 & Nim Busty I & $4.8 \times 10^{3}$ & $3.8 \times 10^{3}$ & $6.6 \times 10^{6}$ \\
20 & Posyore I & 76 & $2.9 \times 10^{3}$ & $3.2 \times 10^{3}$ & $2.5 \times 10^{5}$ \\
\hline
\end{tabular}

population of Ralstonia solacearum $\left(9.8 \times 10^{6}\right)$ was observed in Gorubathan Tar-1 village of Kalimpong. Interestingly, it was also observed that locations in weakly acidic soil with OC percent $>2.25$ had comparatively lower population of $R$. solanacearum $\left(2.5-5.7 \times 10^{5}\right)$ as compared to the other locations in the surveyed area. Microbes confer differential tolerance to extreme pHs. The effect of a soil amendment on the survival of $R$. solanacearum in Philippine soils suggested that a decrease of bacterial population occurred in a soil with a basic $\mathrm{pH}$ (Michel and Mew, 1998). Population dynamics of $R$. solanacearum is strongly influenced by various environmental factors. For instances, highly differential effects of amendment regimes on the survival of $R$. solanacearum occurred in different soil types from various regions (Michel and Mew, 1998; Messiha et al., 2007). There is evidence that the population of $R$. solanacearum race 3 declines in soils that have high organic matter content (Moffet et al., 1983) and higher content of easily decomposable organic matters might be associated with higher microbial activity and ultimately lead to the decline of $R$. solanacearum population.

Thus higher population of $R$. solanacearum may aggravate the disease situation in locations where soil reaction is more acidic and OC percent is less. The present investigation ,therefore, indicated that pathogen population and their survibility may dependent on the soil physicochemical properties and which may ultimately determined the severity of the disease of that particular soil or in that field.

\section{References}

Baruah, T. C. and Barthakur, H. P. 1997. Determination of available potassium in soil. In: A Textbook of Soil Analysis, pp. 8993. Vikas Publishing House, Pvt. Ltd.

Bray, R. H. and Kurtz, L. T. 1945. Determination of total organic and available form of phosphorous in soil. Soil Sci. 59:39-45.

Jackson, M. L. 1967. Soil Chemical Analysis, pp. 387-408. Prentice Hall of India, Pvt. Ltd., New Delhi.

Kim, C. H., Hahn, K. D. and Park, K. S. 1996. Survey of rhizome rot incidence of ginger in major production areas in Korea. Plant Pathol. J. 12:336-344.

Kim, C. H., Yang, S. S. and Hahn, K. D. 1997. Ecology of ginger rhizome rot development caused by Pythium myriotylum. Plant Pathol. J. 13:184-190.

Lee, W. H., Cheong, S. S. and So, I. Y. 1990. Properties of suppressive and conducive soils to ginger rhizome rot. Plant Pathol. J. 6:338-342.

Messiha, N. A. S., van Bruggen, A. H. C., van Diepeningen, A. D., de Vos, O. J., Termorshuizen, A. J., Tjou-Tam-Sin, N. N. A. and Janse, J. D. 2007. Potato brown rot incidence and severity under different management and amendment regimes in different soil types. Euro. J. Plant Pathol. 119:367-381.

Michel, V. V. and Mew, T. W. 1998. Effect of a soil amendment on the survival of Ralstonia solanacearum in different soils. Phy- 
topathology 88:300-305.

Moffett, M. L., Giles, J. E. and Wood, B. A. 1983. Survival of Pseudomonas solanacearum biovars 2 and 3 in soil: effect of moisture and soil type. Soil Biol. Biochem. 15:587-591.

Rajan, P. P., Gupta, S. R., Sharma, Y. R. and Jackson, G. V. H. 2002. Diseases of ginger and their control with Trichoderma harzianum. Indian Phytopath. 55:173-177.

Sarma, Y. R. and Anandaraj, M. 2000. Disease of spices crops and their management. Ind. J. Arecamut Spices Med. Pl. 2:8-20.

Walkley, A. and Black, T. A. 1934. Estimation of soil organic carbon by chromic acid titration method. Soil Sci. 37:29-38. 